\author{
Maja Piotrowska \\ Institute of Philosophy, University of Warsaw \\ National Museum in Warsaw \\ maja.piotrowskatryzno@gmail.com
}

\title{
CONTEMPORARY ARTISTIC TRANSFORMATION OF NATURE IN THE CONTEXT OF THE POLITICS OF NATURE - THE QUESTION OF PARTICIPATION
}

\begin{abstract}
The text compares the concept of participation suggested by Bruno Latour in his Politics of Nature with the 2017 views of Nicolas Bourriaud on the role of art and artist in the dynamically changing world of the Anthropocene. Validating in the context of the goal - building a democratic common world - the role of atomized, grass-root, cognitively eclectic political activity, Latour tries to deactivate the fundamental divisions of the Western ontological tradition (including Nature/Culture and society, object/subject, Science/sciences) as paralyzing the individual's ability to truly engage in the life of a community. He also points to the special role of art, which in the modern Western tradition did not have the ambition of concealing the constructional character of the shared visions of reality. These references are contrasted with the more philosophically traditional attitude of Bourriaud, who defends autonomous art as a value and a sphere that in intimate reception offers a possibility of a particularly accurate representation and at the same time a particularly accurate conceptual simulation of a selected segment of current reality. At the same time, Bourriaud demonstrates a more helpless and pessimistic attitude when compared to Latour's concept of participation, remaining in a world largely created by someone / something else.
\end{abstract}

Keywords: politics of nature, Nature, participation, Parliament of Things, grassroots democratization, Latourian collective, common world, new ontology

On October 6, 2017, Nasher Sculpture Center posted on YouTube a speech by Nicolas Bourriaud, ${ }^{1}$ one of the most influential art critics and curators of our

1 Nicolas Bourriaud: Nasher Prize Graduate Symposium 2017 Keynote, youtube.com/watch?reload $=9 \& \mathrm{v}=8$ FADS5hgB-8, 29.09.2018. 
times, inspired largely by the work of the 2017 Nasher Prize's Laureate, Pierre Huyghe. The work of the French sculptor was recognized by the organization as expanding the possibilities of the genre, not only by using new media and materials, but also by new ways of combining them; such a description may appear not to offer anything really thrilling or awakening - so far. The Nasher Prize is given to those artists that engage powerful ideas and animate sculpture today, the organizers explain further in one of online posts concerning the winners. ${ }^{2}$ The Nasher Prize is important to "featuring public events and educational opportunities" 3 in the city of Dallas (as we may suppose, equally to the whole world of art and outside it), and symbolizes "how we can look beyond our boundaries". In 2017, the Nasher Sculpture Center supported a 'community month', during which the admission was free - they probably significantly increased the number of visitors at that time. The institution is sponsored by (among others) big American corporations, such as J. P. Morgan Chase \& Co., whose representative and "the Nasher Prize presenting sponsor" speaks in the video about recruiting "better people to our area of the country with this fabulous, vibrant art community". "Recruiting better people" at this point of our investigation does not seem to sound very promising given the potentially substantial broadening of the community of ordinary participants. Of course, one may assume that the representative of the big company is simply sincere, which may constitute a preliminary promise/sufficient incentive for the continuation of the investigation concerning the goals of the organizers in 2017. If we make a preliminary assumption that the Nasher Sculpture Center intended to develop the idea of participation, we ought to take a closer look at the direct substantiation of the verdict. Surprisingly, exactly at this moment, at which we could expect it, the presentation of the winner of the Nasher Prize 2017 ends with the scene of handing of the prize without any further explanation. Maybe, announced by the title of the clip the formula of recapitulation proves to be too brief for a viewer not fully familiarized with the concept.

However, we can seek the explanation from Nicolas Bourriaud, the author of the relational aesthetics theory, who presents us with a range of ideas and ideals related to the concept of art he promotes at the moment (represented largely by Pierre Huyghe) in a long speech lasting over an hour described as "The inaugural Nasher Prize Graduate Symposium, conceived to expand scholarship on the field of contemporary sculpture in its many forms" published on YouTube in the category of education. Bourriaud's educational assumption contains numerous philosophical references; as early as at the very beginning,

Nasher Prize 2017 Recap, www.nashersculpturecenter.org/art/nasher-prize, 20.09.2018. Ibid. 
he defines the art of Pierre Huyghe as an "incredible philosophical moment". ${ }^{4}$ It demonstrates both the leading role of philosophy in the discourse of the art world defining the goals of art, and the need to consult philosophy to obtain further, more systematized explanations. We will get acquainted with additional and different explanation during the consideration of the concept of "political ecology" from the Politics of Nature by Bruno Latour 5 , an author who in his search for a new recipe for community and participation does not hesitate to postulate such mockingly shocking solutions as the return of metaphysics, the "Parliament of Things" and the "end of Nature" - the latter, fortunately, only as specifically defined philosophical term. At a closer look, also the "Parliament of Things" appears as a multifunctional philosophical term, one of main purposes of which is to facilitate the functioning of contemporary man.

For now, let us listen to Nicolas Bourriaud, who shares with us particular information that sounds as an answer to Latour's yet unasked question about the status of implementation of the postulate of establishment of the "Parliament of Things"; according to Bourriaud, there is a river in New Zeland, which lately, as the first in the world, gained a special legal status - it was recognized as a living entity, as a person, after seventy years of battle for this by Maori people. The river has now two legal representatives: one belonging to the western cultural tradition and one to the Maori. Such a development can be easily misunderstood by a viewer of news programs as an insignificant local curiosity, but such a perception would be extremely inadequate, as I will try to demonstrate further in this paper. Bourriaud suggests that in our times, we experience systematic challenges of all the classifications, such as: gender, object, or last but not least - art, its genres and techniques; we are assisting a huge movement of recategorization. We have been taught in our tradition that beauty was rather an idea, an essence, and abstraction, what also influenced the art world. It still drives our vision of what art should be. In Hippias Major, continues Bourriaud, when Socrates speaks to Hippias, Plato considers the notion of beauty. For Socrates beauty is something general. Asked for his own definition, Hippias answers that for him beauty is rather something like a pretty girl ("A beautiful girl is beautiful"6). Hippias is depicted as a complete idiot, Bourriaud unsurprisingly concludes. Which does not exclude, however, that nowadays Hippas is someone closer to us than Plato - we are more prone to say that beauty can be a phenomenon, an incident, something happening to

4 Nicolas Bourriaud: Nasher Prize Graduate Symposium 2017 ...

5 See: B. Latour, C. Porter, Politics of Nature. How to Bring the Sciences into Democracy, transl. C. Porter, Harvard University Press, Cambridge, Mass. and London, 2004.

6 W. K. C. Guthrie, A History of Greek Philosophy, Vol. IV: Plato: The Man and his Dialogues: Earlier Period, Cambridge University Press, London, New York and Melbourne 1975, p. 179. 
us. There does not have to be any (well-established, eagerly unifying, we might say) predefined idea of what it should be. Moreover, nowadays art is a kind of permanent challenge to the ideal notion of beauty. Beauty understood as something that is happening points at singular objects with, let us say, liquid, fluctuating categories. In the works of Pierre Huyghe, as Bourriaud interprets them, art happens - it is based on accidents. We may assume, that the French critic first of all thinks here about such realizations by Huyghe as Zoodram sculptures - aquariums featuring exotic sea creatures, and baroque garden for Kassel Documenta 2012 (entitled Untilled), which included, among others, a sculpture of a nude with the head surrounded by a buzzing beehive.

After this swift journey into the realm of beauty conceptualizations, some heavier questions have to be asked, such as one of the most profound: What does constitute the world we live in? Obviously not only objects, supplies Bourriaud, since the world is composed of "things" of a very different nature; in a red carpet there is not only its objectivity of being a carpet, but also of being the color red, our perception of red, our memories associated with it, images of red things (we might add - the happening or/and the epiphany of redness for the viewer ${ }^{7}$ ), and etc. Subsequently, Bourriaud makes a statement concerning the ontological status of all the things he refers to: "they are all equal" in composing reality - the postulate appears that they have equal status in ontological sense. He is talking here about flat ontology relating to French contemporary philosopher Tristan Garcia, who uses the example of redness opting for the equal ontological status for "all things" that are composed of very different nature. Flat ontology creates a space for potential renegotiation of the relations among "things", also for remedying errors of participation; starting with the equalization of statuses, one can search for the spaces (or maybe zones) of the existing exclusion. At the same time, a note of pessimism concerning the world appears there too - Bourriaud invokes another of his favorite artists, presenting him as a creator abstaining from producing material objects, as we already find them too many in this world. As a conclusion to this thread, the logic of capitalism is evoked as responsible for a philosophical fashion - the "object oriented" philosophy. It also seems to be unavoidable force that "commodifies" life and reifies all relations. The relational aesthetics was particularly important in 1990's, when capitalism was starting to merchandise human relations in connection with the development of the Internet, now it has a blitz on life itself.

7 It is one of the unmarked philosophical references built by the speaker - here we should think about Maurice Merleau-Ponty and his unfinished masterpiece The Visible and the Invisible; the example of the philosopher's experience of redness and the memories it evokes constitute already classical, unforgettable passus of contemporary phenomenology. See: M. Merleau-Ponty, The Visible and the Invisible: Followed by Working Notes, transl. A. Lingis, Northwestern University Press, Evastone 1968. 
The frontline today is Anthropocene - human activities significantly modify the conditions of living, forcing the revaluation of our participation in the life on Earth as a species, as well as the revaluation of all relations - also with the products of technology, for example, such as machines. Additionally, we unite in a spontaneous coalition with a part of the living nature we find amicable, facing together apparently destructive system separated from the civil society. ${ }^{8}$

A new political coalition is needed, also entered with "things" and objects. Here, Bourriaud seems to directly refer to Latour, the thinker who has planned the philosophical reconstruction necessary to be carried out in late modernity. We are not going to follow the entire Bourriaud's course of argumentation, we only want to question him about his views and plans concerning a community consisting of persons, phenomena, things, creatures, objects, and how he sees the role of artist in this context in 2017. At certain moment, Bourriaud directly invokes not new philosophical traditions of nominalism and materialism, in which, as he assumes, there is no place for real existence of general concepts - ideas, essences. Each things is in such context singular, one can encounter it, let us say, in person. Bourriaud says that he and the artist, Pierre Huyghe, are on the Hippias side; What really matters, is the moment and the impact of meeting "things" - it is important not to "miss a thing". Does it also mean not to neglect it? We will have to think of it. Disintegration and decategorization also happen in the artist's works, says the critic. Thanks to it the artist is not driven by an abstract conviction of what the art is. Hence, we may expect the opening of the space of happening to uncontrolled possibilities. Huyghe "is [only - M. P.] framing phenomena". We may decide that this way, he shows us a kind of reality, in which people became as unimportant as raw materials in the past. Bourriaud describes the work of Huyghe as new framing in general, as putting the camera in the right place. The camera shows places not noticed before, undervalued and hazardous. Developing the argumentation heading towards hazard, Bourriaud defines the contemporary role of art as signaling; an artist in Anthropocene is someone who sends signals - such a conclusion seems to be the most initially satisfying for me. Of course, one might read this concept of signaling in a manner closer to the older theory of sign, as permanent communication, which is possible on the base of complexity of the work of art. Only this complexity allows us to reinterpret meanings in time, claims Bourriaud. Should there be no sufficient level of complexity, the work of art will change itself into mute matter, the participation of the receiver will disappear.

8 We will think over the weakness of such spontaneous coalition's attitude in the part of the study devoted to the conception of Latour, at the moment we are only critically following Bourriaud. 
Besides, the passion of participation is also necessary - the art is like the light in the fridge - it can be seen only when someone opens the door. In Bourriaud's interpretation, an artist awaits being discovered, simultaneously having something to tell us about hazardous and inevitable changes in our world - he takes a conceptual picture of a fragment of entropic reality for us without freezing it. It is hard not to notice that this position may be interpreted as similar to the one of Cassandra, which is most frequently institutionally separated, isolated and waiting for its advocates, the power of discourses that will support it, when simultaneously we may admire the subtle beauty of its dark melancholy. What's interesting, Bourriaud identifies Latour as one of "the object-oriented philosophers", the contributors to the thread of the contemporary world. The "Parliament of Things" is seen here as inhumane in negative, disturbing sense, as a proposition opposing to the most complex, sophisticated and fragile cultural phenomena, which are protected against the reification with great effort. It seems that at this point we can abandon commenting on Bourriaud's argumentation, as we can roughly see now what the participatory role of artist is and how the recipient participates in art.

Starting to defend Latour, let us get back for a while to the issue of complexity of the message: most likely, Latour would say that the high level of complexity of a message (the complexity of the situation) is necessary to indispensably redefine given formulas of understanding. However, the participation of a recipient depends rather on well-motivated participation game (i.e., as I think, on whether given issue is crucial to the recipient or not). To convoke the new "collective", a new form of community of "things", recruiting them from previously ontologically flattened former hierarchy of beings (Latour does not finish on the flattened ontology), the participating recipient of the world can also "build from the scratch" (providing only that he is sufficiently motivated what here means that he or she has a chance to speak with own voice - to have a decent representation). It happens only on the ground of the conception of Latour that we can claim without a hidden fear of loosing everything what is vividly important to us, that we don't need another (lonely) hero keeping (for long) his/her isolated positions; to start to convoke the potentially meaningful collectives, it is possible for everybody, who has heart; Latour does not hesitate to use such expressions. It seems that following the trace, which he leaves us in the Politics of Nature, we should search for both human and non-human allies - for "things" that we want to represent and take care of in the first place, after having patiently listened to own souls $)^{9}$. What is to be heard are our private

9 In my case, these are secondary qualities - colors, sounds, emotions - associated with idiomatic experience, yet common in people, possible to be derived also from the principle of Kantian sensus communis, associated with individual memory, which is at the same time the 
messages from "things", which everyone of us would like to rescue for others.

The composition of the "new Constitution", which is much more extended than the (modernist) "old Constitution," can contain such elements (actors and actants in Latour's terminology) as elephants, a Maori river, the ozone hole, the presence of cars in the centers of our cities or their lack and replacement by bicycles, Białowieża Forest, dreams, site-specific installations "discovering the beaches under the pavements of the towns", and etc. Latour calls little "collectives" in the state of forming "propositions", which means that they are proposed as important centers of shared interests. Such propositions don't exclude the sciences and gain a chance for appearance/being heard/ - "articulation" - in the common world. For Latour, the more elaborated and complex the articulation, the better. ${ }^{10}$ Well articulated propositions exist longer in the field of view of the bigger collective, which nowadays finds itself in the state of transformation (regarding this last assumption, Bourriaud and Latour seem to agree on the basic level). As it seems, also Latour notes the state of shock resulting from the rapid changes that are happening all the time in the contemporary world. Some potential members of the collective (such as, for example, viruses or plastic in the oceans) are initially considered to be "enemies" and rejected, in order to quickly return with petitions "provided" by their representatives/diplomacy (which means people, procedures and tools involved) - asking for the reconsideration of the admission to the community. The community will be dealing with them - it will talk again about these "things", examine them in various ways, consider the consequences of leaving them astray, plan and implement their transformations after consultations. They have another chance to be taken into consideration during the next "parliamentary session" - on the occasion of the next high increment/accumulation of the unresolved issues that require intervention.

The "new Constitution" from Latour's Politics of Nature is now itself a form only postulated. ${ }^{11}$ The book was published in the first decade of the

tissue of the reflective and the networked, for every human being. Such experiences and memory should be included in a significant way into the "common world" tissue. I am looking for new ways of representation for them. Under the influence of the idea of participation in the new Laturian "collectives" of phenomena, beings and things considered here, I am starting to think about "propositions" such as discussion clubs for significant color memories, with lectures and slides based on biographical experience, but also with some references to culture, or streets being called from the names of colors based on specific, sensitized perceptual experience, e.g. the street named after color of soup made of green peas and cream.

10 This requirement means the necessity of a multistage research and verification, what is supposed to slow down the process of producing objects (the ongoing process of flooding us by material beings, objects and activities that are not being socially consulted).

11 The "old Constitution" that we can remember also from another book by Latour, We Have Never Been Modern, has been described there as an ontological grid producing constantly 
new millennium. The philosopher mentions in it that he has already seen some symptoms of changes, which influenced his conceptualization, but in fact he has on mind rather the world to come. It seems that the political strength of Latour has already led to the first legal empowerment of the Maori river - if one decides to acknowledge these two proposals as building a non-accidental relationship, one could also recognize that the philosophy of this author succeeded in fulfilling its own remarkable promise - the shock of modernity has a chance to lose thanks to it, to some extent, the character of the fatalistic inevitability of a constant confrontation with the outside world, in which we have no visible influence on anything that is vital for us, apart from the strictly private sphere (sometimes). The externality would have a chance to change for the existing community in the emotional way, in accordance with the "Gospel of Saint Bruno's", into the more prone to manifest itself as a refreshing surprise.

It will be appropriate at this point to refer more broadly to the term "nature", which patronizes this text; In Politics of Nature Latour draws attention to the unhappy for us consequences of mononaturalism (the very influential concept of one Nature), which we inherited from modernism. The persistent concept of one Nature causes, says Latour, also the dysfunction of the multiculturalism of more recent date. One of the authorities that can not only be challenged, but even noticed, is naturalization - it usually produces something that is authenticated, equipped with rights, and it seems, that once and for all (e.g. the law of the market); such walls are built to break all the democratic attempts coming from the side of "society" (another totality, treated like a passive whale-island from a fairy tale - is only suitable for being researched and conquered, certainly not for conversation). Latour's political atomization is an attempt to activate "actants" and "actors" - driven by individualized motivations (constructed as "propositions"), that would have a chance to build a real democracy, if the crazy, outdated ontological machinery would not prevent that, nipping in the bud all authentic (resulting from the genuine concerns) manifestations of political initiative. "Sovereign" or the present democracy with its professionalized political class does not seem to work very well, although the latter possesses the skills that are needed in the world of the "new Constitution". In the framework of this Constitution (which means a new organizational principle), the political class would be obliged to cooperate with scientists, administrators, "diplomats" - those who represent, but simultaneously remain engaged in a given case, standing on some side (the requirement of "people with hearts") when considering new proposals, consulting them, approving the borders of the collective

excess things (due to the inviolability of Science), a "democratic" society with no real influence on politics / scientific habits and the powerless / absent God. See: B. Latour, We Have Never Been Modern, transl. C. Porter, Harvard University Press, Cambridge, Mass. 1993. 
anew - it is a process to be repeated. On the remote horizon one can sense the approaching point - it is the paradigm shift; in this postulated new one, the "collective" deals rather with the construction of the good common world, instead of supporting rigidly crypto-theological conceptual authorities that still keep us (as Latour suggests) in the state of Nature-enslavement.

French philosopher distinguishes three stages/modalities of Nature-enslavement, all three still present in our (Western) conceptualization: the "gray nature" means indifferent, cold, dead matter - recalls the prime matter, material prima, from the nigredo phase of the alchemical process. It seems to be at least to some extent a relic of the fight against the unfavorable conditions of the unwanted outside world (the world staying out of the community as a powerful enemy). The "gray nature" seems to be the result of the peak stage of modern anthropomorphization in the social world. The "green nature" is the one that is attempted to be preserved from destruction by the ecologists with more traditional attitude. ${ }^{12}$ Latour assumes that the "green philosopher" with an "oldConstitutional" attitude may exhibit self-destructive/anti-human tendencies in the conditions of Anthropocene. The "red nature" is the absolutization (of dubious provenance) of the principle of survival of the fittest as an indisputable law of evolution of all living organisms that cannot be evaded. In case of the "green nature", we are dealing with the strong opposition to the oppressive paradigm, which remains, however, the conceptual base for this opposition.

Latour does not cut himself off from plants, animals, the planet, the climate, living creatures, even from viruses or prions, nor from the rocks, starving children, pulsars, and etc. He is trying to programmatically build democracy, in which the chance for articulation has, at least according to his assumptions, every proposition that finds (will seek) sufficient support. Important security mechanisms are slowness, accuracy, combining cooperation of sciences and other disciplines when examining propositions, openness and care in the process of "collecting the collective" - adding new propositions. Without superordinate, "pre-existent" totalizing categories warring ontological divisions into binary oppositions, such as Nature and Culture/society, object and subject, etc., it seems quite possible.

It seems that in such a ("young" and open for shaping) world, the role of art would be, first of all, to report specifically (though not uniformly) articulated propositions that particular groups would consider important. Latour recognizes the role of art in shaping the tasks of the collective, while paying

12 Which are contrasted with "political ecology" - the French philosopher is seeing himself as a political ecologist. Political ecology is a term built on the basis of "political economy", of another meaning of course - it refers to systematic thinking of conditions sufficient to build the good common world. 
attention to its special historical status (shared with the law) - art in the Western tradition has always perceived reality as combined with fiction, which means the possibility of negotiation between them. It seems very likely that in the conditions built by the new Constitution site specific art, land art and all kinds of art and projects "green" and "blue" will be/would be still created. ${ }^{13}$ The nature of closely present/close and friendly to humans plants and animals - the dream about the Earthly garden - is very strong proposition, which has been articulated for centuries, ${ }^{14}$ with existing strong representation/diplomacy constituting a large, visible group, that cares about friendly participation of plants and animals in everyday life of people in cities and other habitats, healthy food, the studies on species, relations among them, historical knowledge about the traditions of their coexistence, aesthetical aspects and etc. Here formulates itself one of the "self-lengthening" lists of the many possible, consisting of the topically connected propositions. Potential relations between them, the possibility for the accumulation of knowledge about humans and non-humans, with the last term standing for things, objects and processes, are the initial hopes of the Latour's "pluriverse". As "enemies", there still will/would be suggested in art propositions demanding urgent reflection and investigation (currently such issues as for example GMO or reification; Latour claims the problem of "enemies" would be seen differently after the destruction of the restrictive ontological border separating people from things, which on one hand restricts the sciences dealing with people, and on the other condemns as unreal and at the same time as "absolute domination" things, which are the objects of Science still placed in the context of the old Constitution). The projects prepared for

13 I would like to point here at a wide and intentionally open list of objects and concepts, e.g. the buildings called landscrapers, bubble houses, spectacular architectural design referring to natural microstructures, for example buildings of Zaha Hadid, unrealized projects on the verge of utopia like the one called Dolphin Embassy, assuming a possibility of creating of an open sea meeting place for people and dolphins, ordinary and unusual pools and fountains, sculptural and garden complexes, atria-oases in corporate buildings. An example of bubble house - a project by Michael Sorkin and many examples of landscrapers one can see in Landscrapers. Building with the land by Aaron Betsky (Thames/Hudson, London 2005). The contemporary reference to the original Dolphin Embassy idea can be studied at dolphinembassy.org. See also: hiddenarchitecture.net/2016/02/dolphin-embassy.html.

Let us think about such possibilities as gardens of antiquity, paradise and mythical gardens, refuges, dreams of a perfect habitat, gardens of philosophers, historical gardens-utopias, symbolic places and places of remembrance, of rest-regeneration, for walks, for upbringing. Let us think also of such psychological research branch as environmental psychology, of such branches as the history of farming and agriculture, garden buildings, landscape painting, landscape tourism, botanical gardens and bestiaries - more active enthusiasts of this topicity certainly would notice a much greater number of possibilities for articulating the garden propositions. Many relevant references can be found in G. Świtek, Aporie architektury, Zachęta Narodowa Galeria Sztuki, Warszawa 2012. 
implementation or implemented in the public space as joint representations would have a chance to enjoy the special interest of large groups. To some extent, such phenomena are already visible, although, in the majority of cases, we still cannot submit the sophisticated complaints, supplemented by the expert opinions coming from various orders.

Perhaps, we still cannot imagine such a world. Perhaps we still do not believe that our (potentially common) projects have chances for serious consideration. Both as artists and citizens, we are still assessing the possibility of participating in shaping the common world from our still too powerless, specifically individualized perspective. Most likely, the increase of hope in this matter depends on the number of initiatives arising in spite of the postcolonial "old Constitution", taking into account wide-ranging consultations, which will be able to achieve legal status in the years and decades to come.

\section{BIBLIOGRAPHY}

Betsky Aaron (2005) Landscrapers. Building with the land, London: Thames/Hudson.

Bourriaud Nicolas (2002) Relational Aesthetics, transl. S. Pleasance, F. Woods, Dijon: Les Presses du réel.

Documenta (13) "Untilled" von Pierre Huyghe, youtube.com/watch?v=mEjEy3RY37o [28.09.2018].

dolphinembassy.org [28.09.2018].

Guthrie William Keith Chambers (1975) A History of Greek Philosophy, Vol. IV: Plato: The Man and his Dialogues: Earlier Period, London, New York and Melbourne: Cambridge University Press.

hiddenarchitecture.net/2016/02/dolphin-embassy.html [27.09.2018].

Latour Bruno (2011) Nigdy nie byliśmy nowocześni. Studium z antropologii symetrycznej, transl. M. Gdula, Warszawa: Oficyna Naukowa.

Latour Bruno, Porter Catherine (2004) Politics of Nature. How to Bring the Sciences into Democracy, transl. C. Porter, Cambridge, Mass. and London: Harvard University Press.

Latour Bruno (2009) Polityka natury. Nauki wkraczaja do demokracji, transl. A. Czarnecka, Warszawa: Wydawnictwo Krytyki Politycznej.

Latour Bruno (1993) We Have Never Been Modern, transl. C. Porter, Cambridge, Mass.: Harvard University Press.

Merleau-Ponty Maurice (1968) The Visible and the Invisible: Followed by Working Notes, transl. A. Lingis, Evastone: Northwestern University Press. 
Nasher Prize 2017 Recap, nashersculpturecenter.org/art/nasher-prize [20.09.2018].

Nicolas Bourriaud: Nasher Prize Graduate Symposium 2017 Keynote, youtube.com/watch?relo$\mathrm{ad}=9 \& \mathrm{v}=8$ FADS5hgB-8 [29.09.2018].

Piotrowska-Tryzno Maja, Gurska Aleksandra (2012) Odnaleźć plażę pod ptytami chodnika. Aaron Betsky $i$ 'Landscrapers' $w$ perspektywie filozoficznej, Międzynarodowe Biennale Architektury Wnętrz/International Biennial of Interior Design INAW 2012, Kraków: Biuro Biennale INAW 2012, pp. 66-90.

Świtek Gabriela (2012) Aporie architektury, Warszawa: Zachęta Narodowa Galeria Sztuki.

Sven Beckstette über "Zoodram 6" von Pierre Huyghe, youtube.com/watch?v=1KTUnlBisVw [29.09.2018].

\section{MOŻLIWOŚĆ WSPÓŁCZESNEJ ARTYSTYCZNEJ TRANSFORMA- CJI NATURY W KONTEKŚCIE KONCEPCJI POLITYKI NATURY - PROBLEM PARTYCYPACJI (STRESZCZENIE)}

Tekst zestawia koncepcję partycypacji sugerowaną przez Bruno Latoura w jego Polityce natury z poglądami Nicolasa Bourriauda z roku 2017 na rolę sztuki i artysty w dynamicznie zmieniającym się świecie epoki zwanej antropocenem. Dowartościowując w kontekście celu - budowy demokratycznego świata wspólnego - rolę zatomizowanej, oddolnej, eklektycznej poznawczo działalności politycznej Latour stara się dezaktywować fundamentalne podziały zachodniej tradycji ontologicznej (m.in. na Naturę/Kulturę i społeczeństwo, przedmiot/podmiot, Naukę/nauki) jako paraliżujące zdolność jednostki do autentycznego angażowania się w życie wspólnoty. Wskazuje także na szczególną rolę sztuki, która nie przejawiała w nowożytnej tradycji zachodniej ambicji tuszowania konstrukcyjnego charakteru współdzielonej wizji rzeczywistości. Poszukiwania te skontrastowane zostały z bardziej tradycyjną filozoficznie postawą Bourriauda, broniącego sztuki autonomicznej jako wartości i sfery, która w intymnym odbiorze oferuje możliwość recepcji szczególnie trafnej reprezentacji i jednocześnie szczególnie trafnej konceptualnej symulacji wybranego wycinka rzeczywistości dziejącej się teraz, demonstrującego zarazem, w porównaniu z koncepcją Latoura, większą bezradność i pesymizm jeśli chodzi o możliwości partycypacji w świecie, tworzonym najczęściej przez kogoś/coś innego.

Słowa kluczowe: polityka natury, Natura, partycypacja, Parlament Rzeczy, demokratyzacja oddolna, Latourowski koletyw, wspólny świat, nowa ontologia 